\title{
Hydroethanolic Extracts of Erigeron floribundus and Azadirachta indica Reduced Plasmodium berghei Parasitemia in Balb/c Mice
}

\author{
Roselyne Nzangue Tepongning $\mathbb{D}^{1}{ }^{1}$ Javeres Ntepe Mbah, ${ }^{1}$ Francky Love Avoulou, ${ }^{1}$ \\ Marie Madeleine Jerme, ${ }^{1}$ Evrard-Kevin Kene Ndanga, ${ }^{1}$ and Fabrice Boyom Fekam ${ }^{2}$ \\ ${ }^{1}$ Department of Biomedical Science, University of Ngaoundere, P.O. Box 454, Ngaoundere, Cameroon \\ ${ }^{2}$ Antimicrobial \& Biocontrol Agents Unit, Department of Biochemistry, University of Yaounde I, P.O. Box 812, Yaounde, Cameroon \\ Correspondence should be addressed to Roselyne Nzangue Tepongning; rosytep@yahoo.fr
}

Received 27 June 2018; Revised 24 August 2018; Accepted 1 October 2018; Published 21 October 2018

Academic Editor: Filippo Maggi

Copyright (c) 2018 Roselyne Nzangue Tepongning et al. This is an open access article distributed under the Creative Commons Attribution License, which permits unrestricted use, distribution, and reproduction in any medium, provided the original work is properly cited.

\begin{abstract}
Malaria is one of the most important infectious diseases in Africa especially in Cameroon. The nonaccessibility to current treatments for poor people and the appearance of drug-resistant Plasmodium falciparum parasites stimulate the search for alternative treatments. The aim of this study was to evaluate the antimalarial activity and the safety of hydroethanolic extracts from Erigeron floribundus and Azadirachta indica. The crude hydroethanolic extracts of E. floribundus (HEEF) and A. indica (HEAI) were prepared via maceration of the whole plant powder of E. floribundus and the leaves of $A$. indica in $70 \%$ ethanol. The antimalarial activity was determined according to Peter's 4-day suppressive test using the murine model Plasmodium berghei/Balb $C$ mice, while the acute and subacute toxicity tests were assessed according to the OECD 425 and 407 guidelines, respectively. The results indicate a reduction of parasitemia ranging from $49.75 \pm 3.64$ to $69.28 \pm 1.36 \%$ for HEAI and from $30.46 \pm 4.30$ to $62.36 \pm 2.32 \%$ for HEEI. Overall, HEEF and HEAI at doses of 60, 120, and $240 \mathrm{mg} / \mathrm{kg}$ b.w. and 75, 150, and $300 \mathrm{mg} / \mathrm{kg}$ b.w., respectively, showed a significant $(p \leq 0.001)$ parasitemia reduction on $P$. berghei infecting BALB/c mice. HEEF and HEAI caused a significant $(p<0.001)$ attenuation of body temperature drop in mice compared to negative control, except for the $150 \mathrm{mg} / \mathrm{kg}$ b.w. dose in the female group. Moreover, there was no mice mortality observed with these extracts even at $5000 \mathrm{mg} / \mathrm{kg}$, while the aspartate amino transferase (ASAT) level of mice treated with $300 \mathrm{mg} / \mathrm{kg}$ b.w. of HEAI extract increased when compared with the control. The results of this study support the traditional use of these plants species extracts against malaria infection in rural zones of Northern Cameroon, therefore confirming their potential as sources for the development of efficient phytomedicines for malaria-poverty disease alleviation.
\end{abstract}

\section{Introduction}

Malaria transmitted by a mosquito remains a public health problem with around $88 \%$ diagnosed cases in sub-Saharan Africa. Cameroon is one of the most affected countries in Africa with around 4500 deaths recorded annually, particularly in the Northern region [1]. The strategies applied to eradicate this infection include chemotherapy consisting of antimalarial drugs. However, the recent development of drug-resistant Plasmodium species [2] and the difficulties of infected populations to access the treatments have stimulated the search for alternatives medicines.
Ethnobotanical surveys have been conducted in several regions of Africa and Cameroon, revealing more than 40 medicinal plants species belonging to more than 30 families used in the treatment of malaria [3-7]. A majority of the African population still relies on the use of traditional herbal medicines to treat malaria especially that of Northern Cameroon, influenced by ancestral and religious beliefs, who seldom visits hospitals. Different parts of plants species including leaves, stem barks and roots are frequently used to prepare infusion, concoction, or decoction for the prophylactic and treatment purposes [7], where they are administered 
orally, in bath or steam inhalation for 3 to 6 days, or more often until parasites clearance or not [8].

Azadirachta indica A. Juss is one of the medicinal plants widely used in the treatment of malaria and several diseases in Central and West Africa [9-11]. One well known formulation for infected patient consists of macerating the whole fruits in water for 2 hours, and drinking one-quarter glass three times a day for 5 to 7 days [3]. The traditional use of Erigeron floribundus (Kunth) Schultz-Bip. is not well documented, although ethnobotanical review revealed its antifungal [12], analgesic and anti-inflammatory [13], genital anti-infective [14], and antitussive [15] activities.

For their antiplasmodial potential, several studies reported the efficacy of these two plants extracts. For example, methanolic extracts of $A$. indica was reported to inhibit the growth of chloroquine sensitive strain 3D7 and chloroquine resistant strain Dd2 of Plasmodium falciparum with $\mathrm{IC}_{50}$ values of less than $5 \mu \mathrm{g} / \mathrm{mL}$ [16], while fresh clinical isolates of $P$. falciparum were inhibited with $\mathrm{IC}_{50}$ values of 2 and $16,9 \mu \mathrm{g} / \mathrm{mL}$ for aqueous and methanolic extracts, respectively [17]. Pentane and ethanol extracts of $E$. floribundus were found to inhibit the growth of $P$. falciparum with $\mathrm{IC}_{50}$ values ranging from $15-35 \mu \mathrm{g} / \mathrm{mL}$ [18]. Also, the E. floribundus aqueous extracts were found to inhibit $P$. falciparum amodiaquine-sensitive and resistant isolates, with $\mathrm{IC}_{50}$ values range $6.78 \pm 1.97$ to $26.17 \mu \mathrm{g} / \mathrm{mL}$ [19].

Antimalarial activity studies conducted with $A$. indica derived from the fruit and leaves have evidenced interesting results. Indeed, a prophylactic activity of ethanolic extract of neem fruit was exhibited on BALB/c mice infected with Plasmodium berghei ANKA strain with 43 to $47 \%$ reduction of parasitaemia with respect to controls [20]. Similarly, aqueous extracts from the leaves of $A$. indica showed parasitemia percent chemosuppression of $48.95 \pm 17.58 \%$ and $62.50 \pm 2.05 \%$ at doses of 50 and $100 \mu \mathrm{g} / \mathrm{mL}$, respectively, in Ghana [21]. Although many studies have already reported antiplasmodial activity and toxicity of $A$. indica, no study has yet corroborated this activity for $A$. indica in Cameroon, yet it is a plant with a high consumed in the localities of the north Cameroon. The study of $A$. indica in Cameroon during our study thus finds all its relevance. Similarly and for the best of our knowledge, the antimalarial properties of E. floribundus have not been studied yet.

Given the popular use of $A$. indica and the traditional medicinal value attributed to a little-well known plant, $E$. floribundus, in the Dibi locality, information on their efficacy and safety is relevant to confirm their use. Our study aims at evaluating, comparing the antimalarial potential of the hydroethanolic extracts of the 2 plants using the murine malaria system $P$. berghei/Anopheles stephensi and BALB/c mice and then exploring their safety.

\section{Materials and Methods}

2.1. Plant Collection and Extracts Preparation. The plant samples were collected in the Adamawa Region (locality of Dibi) after interviews among traditional doctors who gave their consent to talk about malaria, from the 29 December
2014 to the 08 January 2015. Information gathered from traditional doctors was needful to identify the plants used in the selected area for the management of malaria. These plants were harvested according to interview details early in the morning before sunrise. They were later identified by a plant taxonomist and further confirmation was made at the National Herbarium in Yaounde, Cameroon. The questionnaire used during the interview included information on the local use, the local name, the mode of preparation, the forms of administration of the medicinal plants, the parts of the plants used, the dosage and duration of the treatment, and recipes for the management. Among these selected plants, two plants were chosen for this preliminary study: E. floribundus (scarce) and A. indica (abundant) and voucher specimens are deposited at the National Herbarium Cameroon with reference numbers of 11132/HNC and $4447 /$ SRFK, respectively. The plant sampling was done in accordance with the Convention on the Trade in Endangered Species of Wild Fauna and Flora.

The entire plant of E. floribundus and leaves of A. indica were cut into small pieces, dried at laboratory temperature $\left(25^{\circ} \mathrm{C}\right)$ for two weeks till constant weight and powdered. Powdered plant materials $(100 \mathrm{~g})$ were macerated in 1500 $\mathrm{mL}$ of ethanol/water (70:30) for $24 \mathrm{~h}$ at room temperature. The resulting extract was filtered and evaporated using a rotary evaporator at $40^{\circ} \mathrm{C}$. The residues which constitute the crude extracts were recovered in flasks and then left in an oven at $40^{\circ} \mathrm{C}$ until complete evaporation of the solvent. All extracts were then kept at $4^{\circ} \mathrm{C}$ until further use. The different doses of plant extract were prepared using $100 \mathrm{mg} / \mathrm{mL}$ stock solutions.

2.2. The Animals. For in vivo antimalarial assay, $8-12$ weeks old $\mathrm{BALB} / \mathrm{c}$ mice ( 60 male and 60 female) weighing between 20 and $30 \mathrm{~g}$ were used. For toxicity test, 6 to 8 weeks old Rattus norvegicus rats (40 male) weighing between 100-180 $\mathrm{g}$ were used. The animals were obtained from the National Veterinary Laboratory (Garoua-Cameroon) and were kept in laboratory conditions for two weeks before the experiment. These conditions included: temperature $22^{\circ} \mathrm{C}\left( \pm 3^{\circ}\right), 12 \mathrm{~h}$ light/dark cycle, food and water provided ad libitum. All experiments were conducted according to the European Union guidelines for experimentation on laboratory animals (Directive 2010/63/EU of 8 August 2010 on the protection of animals used for scientific purposes).

2.3. In Vivo Antimalarial Activity of Extracts. The antimalarial potency of extracts was studied as described in the classical 4-day suppressive test of Peters [22]. Briefly, mice were inoculated intraperitoneally with $200 \mu \mathrm{L}$ of $1 \times 10^{7} \mathrm{P}$. berghei NK65 strain in blood. Three hours after, HEEF and HEAI extracts were administrated orally. The treatment was carried out for 4 days. Doses used were 60,120 and $240 \mathrm{mg} / \mathrm{kg}$ for HEEF and 75, 150 and $300 \mathrm{mg} / \mathrm{kg}$ for HEAI. The group considered as negative control received $200 \mu \mathrm{L}$ of distilled water, while the group of positive control received $10 \mathrm{mg} / \mathrm{kg}$ of quinine. 
Smears were prepared on the fifth day and the parasitemia was determined microscopically (magnification x100) using the following formula of Zucker and Campbell [23]:

$$
\% \text { Parasitemia }=\frac{\text { Number of infected red blood cells }}{\text { Total number of red blood cells examined }} \times 100
$$

The efficacy of the treatment for each extract was evaluated by calculating the average percent reduction of parasitemia according to equation 2 :

$$
\% \text { reduction }=\frac{C-T}{C} \times 100
$$

$\mathrm{C}$ is mean parasitemia percentage in the negative control group and $\mathrm{T}$ is mean parasitemia percentage in the treated group.

During the 4-day suppressive test, the body temperature of each mouse was determined before infection on day 0 and after the treatment on day 4 using a rectal thermometer. The method involves inserting a small diameter temperature probe covered with Vaseline through the anus of the mouse. Before that the mouse is hand-restrained and placed on a horizontal surface and its tail lifted.

2.4. Evaluation of Acute Toxicity. The acute toxicity of HEEF and HEAI was evaluated in female mice according to the OECD 425 guidelines [24] for trials using chemical substances. The test substance was given sequentially in a single dose of $2000 \mathrm{mg} / \mathrm{kg}$ to a total of five mice, using a stomach tube. Later, the substance was administered sequentially at a dose of $5000 \mathrm{mg} / \mathrm{kg}$ to a single animal up to three animals at 48 hours interval. After administration, animals were observed individually at least once during the first 30 minutes after dosing; the operation was repeated periodically during the first 24 hours (with special attention given during the first 4 hours) and daily thereafter, for a total of 14 days. The animals weights were measured on days 0,7 , and 14 after administration then the survived animals were subjected to gross necropsy at the end of the test period to evaluate pathological changes.

2.5. Evaluation of Subacute Toxicity. The subacute toxicity profile of HEEF and HEAI was evaluated using male rats according to OECD 407 guidelines [25]. Briefly, for each group of 5 rats, oral doses of 60,120 , and $240 \mathrm{mg} / \mathrm{kg}$ for HEEF and 75,150 , and $300 \mathrm{mg} / \mathrm{kg}$ of HEAI were administrated daily for 28 days. The control group received the distilled water. The weight of each animal was recorded weekly during the experimental period and the signs of toxicity or mortality observed.

2.6. Serum Preparation and Macroscopic Analyses of Organs. Twenty-eight days after administration of extracts, animals were fasted overnight and sacrificed. Blood samples were collected by cardiac puncture and centrifuged at $3000 \mathrm{rpm}$ for $5 \mathrm{~min}$ to obtain serum. The organs including the liver, the heart, the kidney, the spleen, and the lung were removed, observed, and weighed.

2.7. Measurement of Biochemical Parameters. At the end of the repeated dose 28-day oral toxicity study, blood collected from thiopental anesthetized rats by cardiac puncture was introduced in tube, swirled, and placed on ice. The serum was obtained by centrifugation at $3000 \mathrm{rpm}$ for $5 \mathrm{~min}$ for biochemical measurements, using Biolabo commercial diagnosis kits for creatinine (80107), alanine aminotransferase (92027), and aspartate aminotransferase (92025).

2.8. Data Analysis. Quantitative data were expressed as arithmetic mean \pm standard deviation (SD) of three to six replicates. To compare the parasitemia level, the independent samples Student's t-test was used, and one-way analysis of variance (ANOVA) followed by the Tukey HSD post hoc tests applied for the other results. Mean values were considered to be statistically significant at $\mathrm{p}<0.05$.

\section{Results}

3.1. Plant Selection. At the end of the ethnobotanical survey in the locality of Dibi, Adamawa Region, 11 plants were recorded to be used for antimalarial cure (Supplementary Material 1). Plants were A. indica, Tamarindus indica, Carica papaya, Senna occidentalis, Eucalyptus sp., Bidens pilosa, Lantana camara, Achyranthes aspera, Spermacoce stachydea, Aloe vera, and E. floribundus. Two plants (A. indica and E. floribundus), the most known/studied and the least cited, respectively, were selected for biological assessment.

3.2. Plant Preparation and Administration. The results of ethnobotanical study in Dibi locality revealed that maceration $(45.5 \%)$ and decoction $(72.7 \%)$ were the modes of preparation used by traditional doctors for malaria remedies (Supplementary Material 1). Fresh parts of the plant were generally used to treat malaria except for A. indica, C. papaya, S. occidentalis, and Eucalyptus sp. stored as dried powders in closed bottles. Most plants were administered orally (84.4\%), soaked in hot or cold water, and taken orally as the active medicine. Only vapors of $A$. indica were inhaled during the treatment. The plant parts collected were leaves, roots, bark, and flowers/fruits. Remedies based on mixtures of different plants were also common.

The amounts of solution used for remedy recorded during the survey were described in terms of a full, half, or quarter of a cup of $250 \mathrm{~mL}$ to be taken two or three times a day for three to seven days or until the patient is healed. Different 


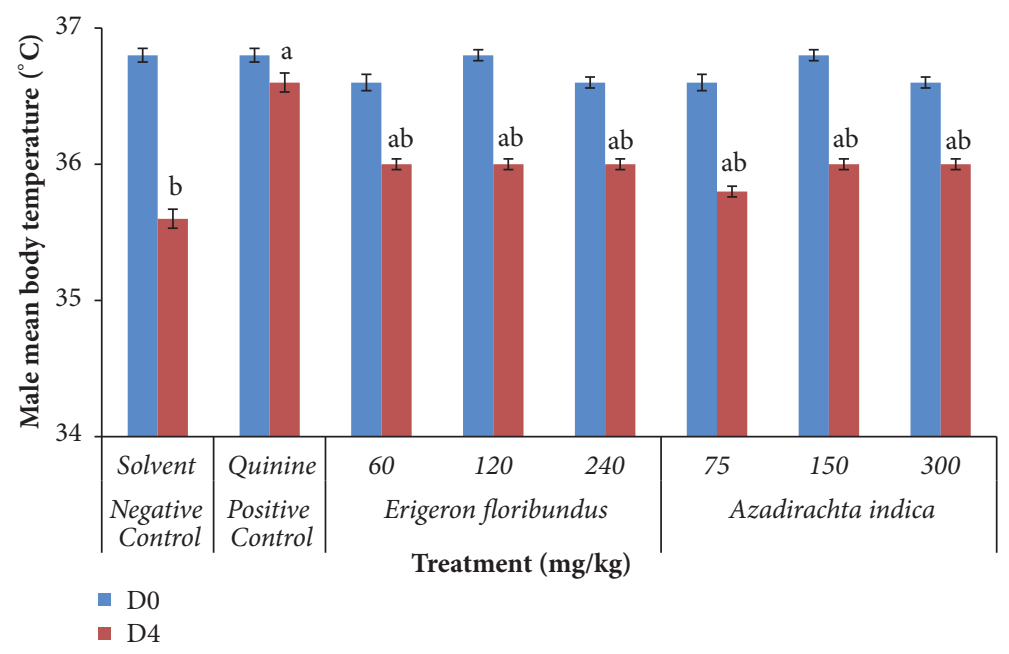

FIGURE 1: Effects of E. floribundus and A. indica hydroethanolic extracts on the temperature of parasitized male mice. D0: day 0; D4: day 4; $\mathrm{n}$ $=6 ;{ }^{\mathrm{a}} \mathrm{p}<0.05$ compared to negative control at day $4 ;{ }^{\mathrm{b}} \mathrm{p}<0.05$ compared to positive control at day 4 .

dosages for the same preparation were described by different healers. The most common usage was to keep the preparation in the jar of $500 \mathrm{~mL}, 1 \mathrm{~L}, 1,5 \mathrm{~L}$, and $5 \mathrm{~L}$. No clear pattern or any consistency existed between healers as far as dosage was concerned.

The extraction yield of the hydroethanolic extracts of the two selected plants was $14 \%$ and $16 \%$ for E. floribundus (HEEF) and A. indica (HEAI), respectively.

3.3. Antimalarial Activity. Plant extracts administered at different doses reduced parasitemia in $P$. berghei infected mice in a dose-dependent manner. In fact, at doses of 60, 120, and $240 \mathrm{mg} / \mathrm{kg}$, the hydroethanolic extract of E. floribundus (HEEF) reduced the parasitemia by $30.5,57.3$, and $62.4 \%$ and $39.6,57.3$, and $62.2 \%$ for female and male mice, respectively (Table 1).

At the doses of 75, 150, and $300 \mathrm{mg} / \mathrm{kg}$ for the hydroethanolic extract of $A$. indica (HEAI), there was a reduction of parasitemia by $49.8,55.2$, and $68 \%$ and $50.8,55.9$, and $69.3 \%$, respectively, for female and male mice (Table 2 ).

The most efficient doses of extracts for female and male mice were $120 \mathrm{mg} / \mathrm{kg} / \mathrm{day}$ for $\operatorname{HEEF}(57.3 \pm 3.8 \%-57.3 \pm$ $3.9 \%)$ and $300 \mathrm{mg} / \mathrm{kg} /$ day ( $68 \pm 1.1 \%-69.3 \pm 1.4 \%)$ for HEAI. Moreover, no significant difference between the effects of HEEF extract was found at doses 120 and $240 \mathrm{mg} / \mathrm{kg}(\mathrm{p}>0.05)$. Despite the inhibitory effect of HEAI and HEEF extracts, their activity was far less important compared to that of quinine that showed an activity 70 to 140 times more strongly than the investigated extracts.

3.4. Effects of E. floribundus and A. indica Extracts on Parasitized Mice Temperature. None of the doses of E. floribundus and $A$. indica extracts significantly improved the body temperature of $P$. berghei infected mice at day 4 compared to day 0 as indicated in Figures 1 and 2. P. berghei infected mice treated with hydroethanolic E. floribundus and A. indica extracts reduced the body temperature from $36.6-36.8^{\circ} \mathrm{C}$ for male and $36.8-37.1^{\circ} \mathrm{C}$ for female at day 0 to $35.8-36^{\circ} \mathrm{C}$ for male and $35.6-36^{\circ} \mathrm{C}$ for female on day 4 , corresponding to temperature drop of 0.6 to $0.8^{\circ} \mathrm{C}$ for male and 0.8 to $1.6^{\circ} \mathrm{C}$ for female mice, respectively. In the control groups, temperature reduction was $1.2^{\circ} \mathrm{C}$ for male and $1.6^{\circ} \mathrm{C}$ for female in the negative control and $0.2^{\circ} \mathrm{C}$ for male and none for female in the positive control. Overall, HEEF and HEAI extracts caused significant $(p<0.05)$ but not dose-dependent drop of mice's temperature in the range of $0.4-0.6^{\circ} \mathrm{C}$ for male (Figure 1 ) and $0.8-1.2^{\circ} \mathrm{C}$ for female (Figure 2 ) when compared to the positive controls, as well as a significant $(p<0.001)$ attenuation of the body temperature drop in mice compared to negative control, except for the $150 \mathrm{mg} / \mathrm{kg}$ dose in the female group (Figure 2).

3.5. Acute Toxicity Study. Over the 14 days period following administration of extracts to $R$. norvegicus at doses of $2000 \mathrm{mg} / \mathrm{kg}$ and $5000 \mathrm{mg} / \mathrm{kg}$, neither significant behavioural changes, nor morbidity/mortality was recorded among tested animals. The $50 \%$ lethal dose $\left(\mathrm{LD}_{50}\right)$ was therefore considered to be higher than $5000 \mathrm{mg} / \mathrm{Kg}$ for both plants extracts. Moreover, no animals showed changes in the overall appearance and the somatosensory motricity during the observation period. No manifestation of tremors, convulsions, salivation, diarrhoea, coma, or abnormal behaviours such as self-injury or walking backward was observed for the two extracts. However, sleep events were observed in all animals during the first 30 minutes upon gavage. This sleep was fleeting in controls but was reversible after a few hours in the treated animals (Supplementary Material 2). In addition, the animal body weight did not significantly increase during the test period with a maximum weight gain of $2.6 \mathrm{~g}$ for the treated groups compared to $2.7 \mathrm{~g}$ in the control group (Table 3).

3.6. Effect of Subacute Extracts Administration on the Behaviour and the Relative Body Weight of Rats. Rats were daily administered oral doses of extracts $A$. indica at 75, 150, and $300 \mathrm{mg} / \mathrm{kg}$ b.w. and E. floribundus at 60, 120, and 240 


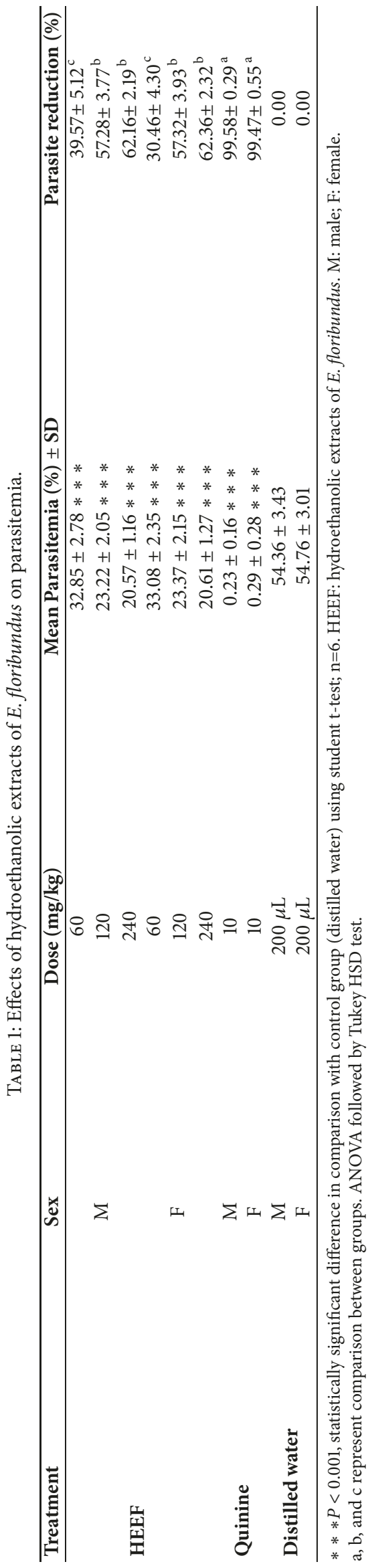




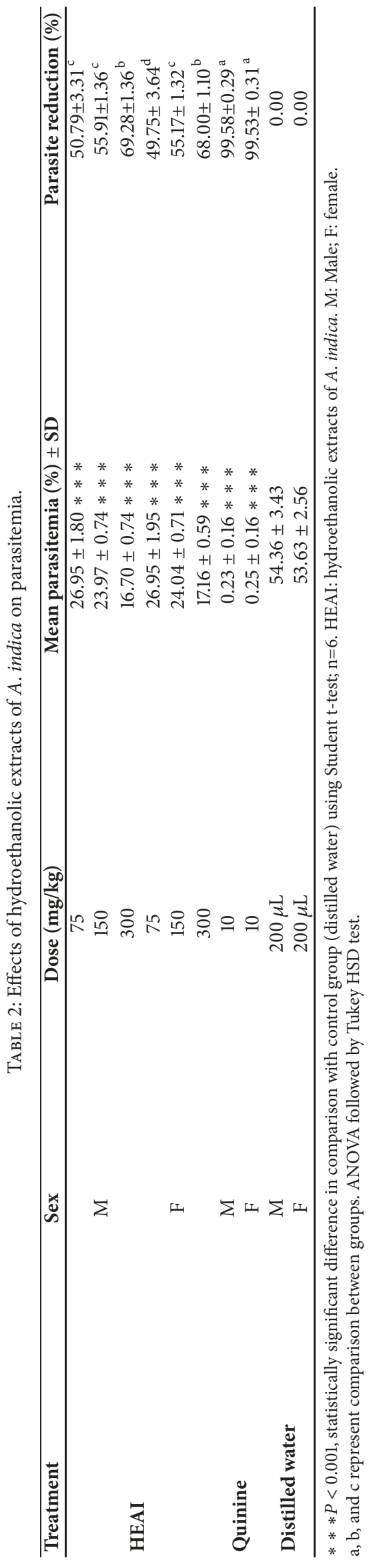




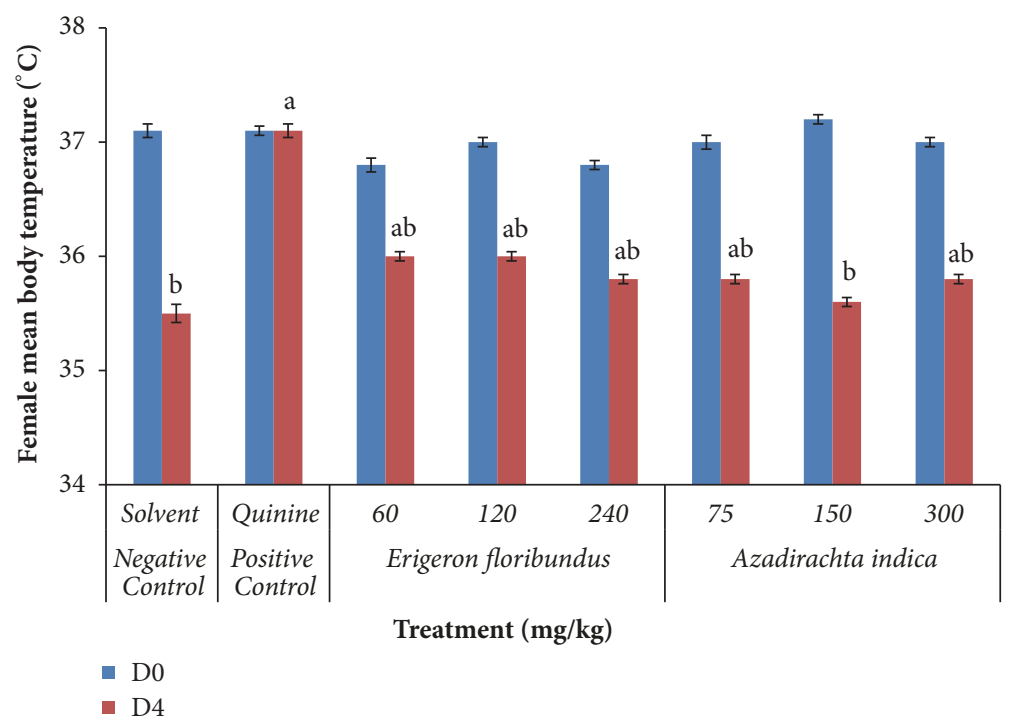

FIGURE 2: Effects of E. floribundus and A. indica hydroethanolic extracts on the temperature of parasitized female mice. D0: day 0; D4: day 4; $\mathrm{n}=6 ;{ }^{\mathrm{a}} \mathrm{p}<0.05$ compared to negative control at day $4 ;^{\mathrm{b}} p<0.05$ compared to positive control at day 4 .

TABLE 3: Body weights of mice subjected to acute toxicity assessment of the hydroethanolic extracts of E. floribundus and A. indica.

\begin{tabular}{|c|c|c|c|}
\hline \multirow{2}{*}{ Groups } & \multicolumn{3}{|c|}{ Body weight $(g) \pm S D$} \\
\hline & Day 0 & Day 7 & Day 14 \\
\hline \multicolumn{4}{|c|}{ (A) Mice treated with HEEF } \\
\hline Control & $22.0 \pm 0.7$ & $23.7 \pm 0.9$ & $24.8 \pm 0.6$ \\
\hline $2000 \mathrm{mg} / \mathrm{kg}$ & $23.3 \pm 0.9$ & $24.0 \pm 0.7$ & $24.9 \pm 0.5$ \\
\hline $5000 \mathrm{mg} / \mathrm{kg}$ & $22.1 \pm 0.3$ & $23.2 \pm 0.7$ & $24.1 \pm 0.2$ \\
\hline \multicolumn{4}{|c|}{ (B) Mice treated with HEAI } \\
\hline Control & $22.0 \pm 0.7$ & $23.7 \pm 0.9$ & $24.8 \pm 0.6$ \\
\hline $2000 \mathrm{mg} / \mathrm{kg}$ & $22.1 \pm 0.7$ & $23.3 \pm 0.3$ & $24.6 \pm 0.3$ \\
\hline $5000 \mathrm{mg} / \mathrm{kg}$ & $22.0 \pm 0.6$ & $22.5 \pm 1.0$ & $24.7 \pm 0.8$ \\
\hline
\end{tabular}

Female mice were administered a single dose of each plant extract at doses of $2000 \mathrm{mg} / \mathrm{kg}(5)$ and $5000 \mathrm{mg} / \mathrm{kg}$ (3) and mean body weight was recorded before the treatment (day 0 ) and on days 7 and 14 . The control group received $200 \mu \mathrm{L}$ of distilled water. HEEF; hydroethanolic extracts of E. floribundus; HEAI: hydroethanolic extracts of $A$. indica.

$\mathrm{mg} / \mathrm{kg}$ b.w. for a period of 28 days. Upon treatment, no change was observed in the animals during the whole period of treatment. The rats normally grown over the 28 days period of treatment in the treated and control groups as indicated in Table 4, with a weight gain of approximately 10 to $20 \mathrm{~g}$.

The profiles of the biochemical parameters (ALAT, ASAT, and creatinine) evaluated upon treatment with E. floribun$d u s$ and $A$. indica extracts indicated no overall significant changes. However, ASAT level increased in the group of animals treated with $A$. indica extract at a dose of $300 \mathrm{mg} / \mathrm{kg}$ b.w. when compared to the control group (Table 5).

On day 28, an autopsy of the animals revealed a general darkening of the liver with the presence of nodules in animals treated with $A$. indica at a dose of $300 \mathrm{mg} / \mathrm{kg} \mathrm{b.w.} \mathrm{and} \mathrm{two}$ animals treated with E. floribundus at doses of $120 \mathrm{mg} / \mathrm{kg}$ and $240 \mathrm{mg} / \mathrm{kg}$, respectively, compared to the controls. An examination of the thoracic cavity revealed the presence of nodules in the lungs of two animals, respectively, treated with the extracts of $A$. indica at $150 \mathrm{mg} / \mathrm{kg}$ b.w. and E. floribundus at $120 \mathrm{mg} / \mathrm{kg}$ b.w. when compared to the negative controls. Also, the kidney of one animal treated with E. floribundus at $240 \mathrm{mg} / \mathrm{kg}$ b.w. was atrophied. Besides, all the organs of the other animals presented no distinctive sign-treatment effects compared to the negative control animals. Nevertheless, no differences were observed in weights of organs, namely, lungs, livers, kidneys, hearts, and spleens between treated and control mice (Table 4).

\section{Discussion}

Medicinal plants have shown to be interesting sources of potent antimalarial drugs. Thus, this study examined the in vivo potency of $E$. floribundus and $A$. indica extracts against $P$. berghei NK65 strain in infected mice. The results of this study showed that the hydroethanolic extracts of $E$. floribundus and $A$. indica reduced the parasitemia of $P$. berghei in white BALB/c male and female mice in a range of 30-69\%. This range of inhibition may be considered as the 


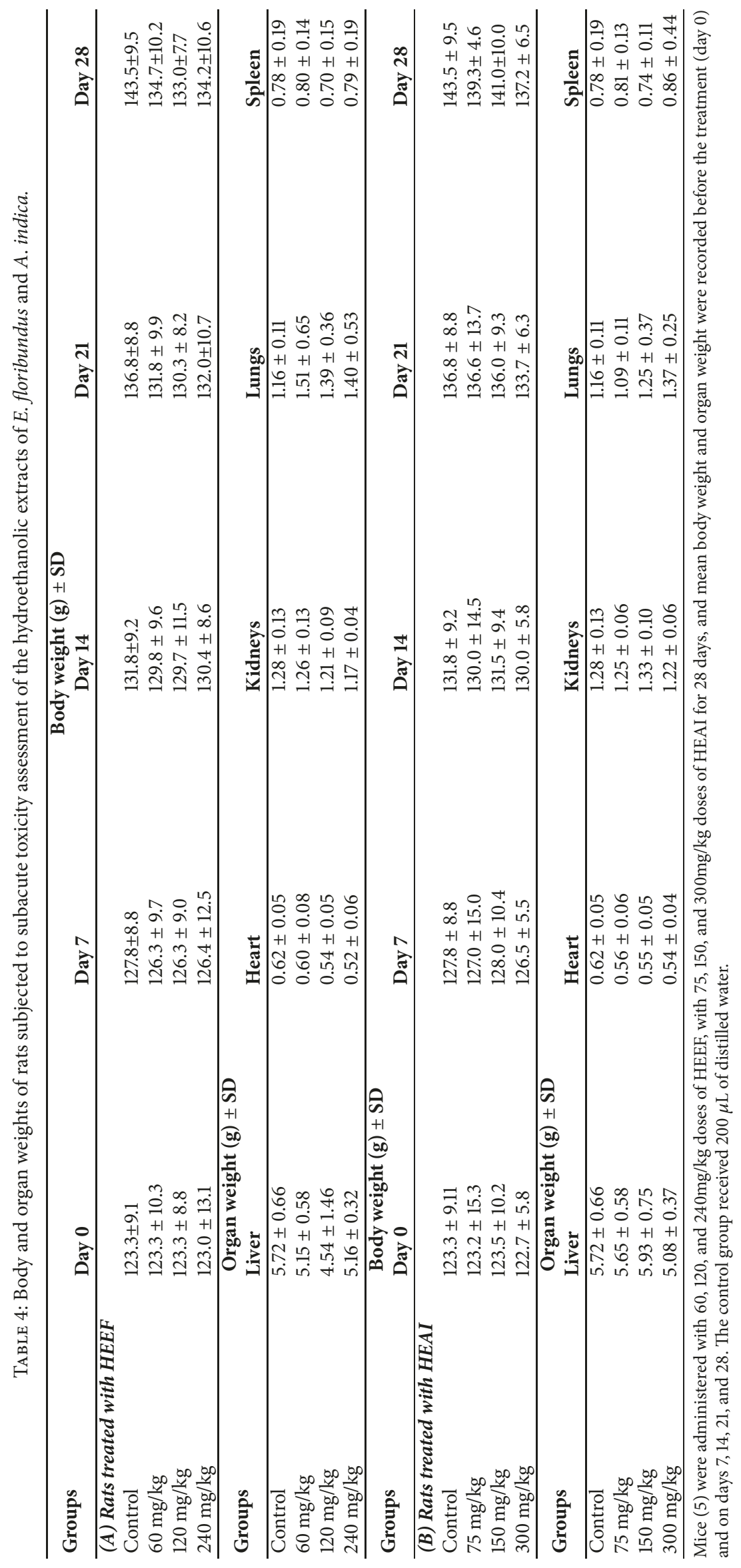


TABLE 5: Effects of E. floribundus and A. indica hydroethanolic extracts on biochemical parameters.

\begin{tabular}{lccc}
\hline Dose $(\mathrm{mg} / \mathrm{kg})$ & ALAT $(\mathrm{U} / \mathrm{L})$ & $\begin{array}{c}\text { Parameter } \\
\text { ASAT }(\mathrm{U} / \mathrm{L})\end{array}$ & Creatinine $(\mathbf{m g} / \mathbf{L})$ \\
\hline (A) Mice treated with HEEF & & & \\
Control & $55.00 \pm 6.1^{\mathrm{a}}$ & $153.85 \pm 18.5^{\mathrm{a}}$ & $4.83 \pm 0.4^{\mathrm{a}}$ \\
$\mathbf{6 0}$ & $54.67 \pm 10.8^{\mathrm{a}}$ & $181.45 \pm 22.6^{\mathrm{a}}$ & $4.72 \pm 0.3^{\mathrm{a}}$ \\
$\mathbf{1 2 0}$ & $53.33 \pm 7.0^{\mathrm{a}}$ & $162.35 \pm 11.5^{\mathrm{a}}$ & $4.57 \pm 0.2^{\mathrm{a}}$ \\
$\mathbf{2 4 0}$ & $49.00 \pm 11.9^{\mathrm{a}}$ & $175.08 \pm 36.6^{\mathrm{a}}$ & $4.88 \pm 0.6^{\mathrm{a}}$ \\
$(\boldsymbol{B})$ Mice treated with HEAI & & & \\
Control & $55.00 \pm 6.1^{\mathrm{a}}$ & $153.85 \pm 18.5^{\mathrm{a}}$ & $4.83 \pm 0.4^{\mathrm{a}}$ \\
$\mathbf{7 5}$ & $64.67 \pm 174^{\mathrm{a}}$ & $203.93 \pm 42.1^{\mathrm{a}}$ & $4.50 \pm 0.7^{\mathrm{a}}$ \\
$\mathbf{1 5 0}$ & $61.33 \pm 17.4^{\mathrm{a}}$ & $191.38 \pm 36.3^{\mathrm{a}}$ & $4.30 \pm 0.5^{\mathrm{a}}$ \\
$\mathbf{3 0 0}$ & $58.66 \pm 12.7^{\mathrm{a}}$ & $213.58 \pm 30.5^{\mathrm{b}}$ & $4.55 \pm 0.2^{\mathrm{a}}$ \\
\hline
\end{tabular}

$\mathrm{a}$ and $\mathrm{b}$ represent comparison between groups. ANOVA followed by Tukey HSD test. $\mathrm{n}=6$. HEEF: hydroethanolic extracts of E. floribundus; HEAI: hydroethanolic extracts of $A$. indica.

moderate antimalarial activity as otherwise stated [26]. This result is consistent with data from in vivo studies carried out with different extracts of $A$. indica $[9,10,21]$.

In this preliminary study adopting protocols which simulate the recommendation of traditional healers in terms of dosage and solvents, the comparative antimalarial activity observed between the plants, combined with the safety of $E$. floribundus, supports its traditional use for the management of malaria in the locality of Dibi. This plant may also be used as alternative in the locality as $A$. indica present signs of toxicity at a high dose.

In the oral route, bioactive molecules cross several barriers and enzymatic systems before reaching the systemic circulation, the consequence being the modification of bioactive molecules by metabolism, and thus either improve or reduce the antiplasmodial activity. This suggested that the antiplasmodial activity of metabolically activated compounds can also be observed in vivo analysis.

In fact, the antimalarial activity observed could be ascribed to secondary metabolites that are present in A. indica and E. floribundus extracts. A. indica known as neem is a rich source of alkaloids, terpenoids, steroids, tannins, and flavonoids that were previously shown to have antiplasmodial activity [27]. Moreover, gedunin, nimbinine, azadirachtin, and salannin isolated from neem were found to display very high in vitro antiplasmodial activity against sensitive and resistant strains of P. falciparum [28, 29]. Compounds from $E$. floribundus also demonstrated interesting activities, including limonene with $\mathrm{IC}_{50}$ values between 0.5 and 9.8 $\mu \mathrm{g} / \mathrm{mL}$ against $P$. falciparum $\mathrm{FcB} 1[30,31]$. In addition, $E$. floribundus is also rich in flavonoids, saponins, polyphenols, alkaloids, glycosides, and tannins [14]. It is most abundant phenolic compounds named caffeoyl quinic derivatives which displayed moderate to weak ( $\mathrm{IC}_{50}>29 \mu \mathrm{M}$ ) antiplasmodial activity against $\mathrm{HB} 3$ and $\mathrm{Dd} 2$ strains of $P$. falciparum $[32,33]$ while luteolin, quercetin, and apigenin demonstrated previously moderate activity of less than $20 \mu \mathrm{M}$ against 3D7 and 7G8 strains of P. falciparum [34]. However, further investigation on metabolites rich fraction especially for the not well known plant E. floribundus harvested in the
Dibi locality should provide more information regarding the potent antimalarial compounds.

As stated overhead, previous studies on in vivo antimalarial activity of $A$. indica have also been catalogued to discuss our results. Kingsley et al. (2012) tested the aqueous extract of $A$. indica leaves and got parasite reductions of $48.95 \%$ at 50 $\mathrm{mg} / \mathrm{kg}$ and of $62.50 \%$ at $100 \mathrm{mg} / \mathrm{kg}$ [21], close to our results. Similarly, Oseni and Akwetey [10] study demonstrated that aqueous and ethanolic extracts of $A$. indica at dose of 50, 100 , and $200 \mathrm{mg} / \mathrm{kg} /$ day caused chemosuppression of 56.96, $59.89,69.49 \%$ and $56.96,63.15,69.60 \%$, respectively, on day four, activities superior to ours. Farahna et al. in 2010 found a parasite reduction of $22.8 \%$ at $300 \mathrm{mg} / \mathrm{kg}$ with an ethanolic extract of $A$. indica leaves [9], lower than ours at the same dose although many factors such as extraction solvent and protocol or harvesting period can influence the results. For the second plant E. floribundus, this is the first time that its potential antimalarial activity is mentioned in the literature.

In our study, the use of ethanol solvent combined to water at a proportion 70:30 did not increase significantly the activity of the plants compared to studies done using a single solvent [10]. Much remains to be done to identify the best solvent and/or the good proportion to be used for substantial enhancement in the antimalarial activity of $A$. indica and $E$. floribundus. Similarly, studies are scheduled to confirm this activity at higher doses.

Rectal thermometry is a common method of measuring body temperature in rodents to control energy balance or energy metabolism in vivo. Anemia, body weight loss, and temperature reductions are common characteristics of $P$. berghei infected mice [35]. A decrease in the metabolic rate of infected mice occurs before death and is accompanied by a corresponding decrease in internal body temperature [36]. So, ideal antimalarial agents obtained from plants are expected to prevent these decreases in infected mice due to the rise in parasitemia. Knowing that the normal temperature of $\mathrm{Balb} / \mathrm{c}$ mice varies between $36.5^{\circ} \mathrm{C}$ and $38^{\circ} \mathrm{C}$, the hydroethanolic extracts of E. floribundus and A. indica significantly induced body temperature drop on day 4 compared to quinine, the recommended drug for severe malaria, 
but also prevented the temperature decrease due to infection compared to negative controls. The same observation was previously reported and confirmed for Plasmodium infected mice [37-39].

In order to gain information on extract's toxicity in animals and verify its direct relevance for protecting human or animal health, an acute toxicity test at limit doses of 2000 then $5000 \mathrm{mg} / \mathrm{kg}$ b.w. was performed. The results suggested an $\mathrm{LD}_{50}$ dose higher than the limit dose 5000 $\mathrm{mg} / \mathrm{kg}$ classifying our extracts as practically nontoxic and without any risk for human health as reported in the OECD guidelines [24]. This finding is consistent with a reported $\mathrm{LD}_{50}$ oral dose of ethanolic extract of $A$. indica of higher than $2000 \mathrm{mg} / \mathrm{kg}$, [40] confirming the clinical safety of the plant [10]. Apart from the study on Conyza sumatrensis [41], a synonym of E. floribundus, showing no mortality for up to $3000 \mathrm{mg} / \mathrm{kg}$ in acute toxicity and nonsignificant changes in rats for up to $1000 \mathrm{mg} / \mathrm{kg}$ dose in the subchronic study, little information is available on the effect of E. floribundus extracts on animals if not the drowsiness and the tiredness observed on rats receiving aqueous extract of the same plant at doses of 1600 and $3200 \mathrm{mg} / \mathrm{kg}$ b.w. [15].

A subacute toxicity was also performed in this study to evaluate possible adverse effects of repeated extract's administration to rats, at doses corresponding to those of antimalarial assessment. No significant change was observed in body and organ weights of rats, as well as in biochemical parameters except an increase in serum ASAT at dose of 300 $\mathrm{mg} / \mathrm{kg} /$ day, suggesting muscular dysfunction or damage to internal organs. In fact, the body weight changes are markers of adverse effects of drugs and chemicals, considered as statistically significant if a body weight loss is of more than $10 \%$. Organ weight also is an important indicator of physiological and pathological status of animals, fundamental to confirm whether the organ was exposed to lesions or not [42]. Indeed, symptoms of neurological or respiratory disorder and mortality were recorded in mice receiving ethanolic extract of neem at doses up to $1000 \mathrm{mg} / \mathrm{kg}$ due to $P$. berghei infection [9]. Macroscopic exams showed in this study that the target organs of $A$. indica and E. floribundus hydroethanolic extracts were lungs, liver, and kidneys at doses between 120 and 300 $\mathrm{mg} / \mathrm{kg} /$ day. The heart, liver, kidney, spleen, and lungs are the primary organs affected by metabolic reaction caused by toxicant; blood urea nitrogen (BUN) and creatinine, the parameters to evaluate kidney function and transaminases such as ALAT and ASAT, the good indicators of liver function used as biomarkers of drugs toxicity [42].

\section{Conclusion}

At the end of this study, E. floribundus and A. indica extracts have reduced the parasitemia in $P$. berghei infected mice in dose-dependent manner, supporting the traditional use of these plant species by Dibi population of Adamawa Region in the management of malaria and related symptoms. The implication of this finding is that hydroethanolic extracts possesses antimalarial effect and may, therefore, serve as potential sources of safe, effective, and affordable antimalarial drugs. Further research focused on toxicity studies coupled with a histological examination of treated animals should provide more information regarding the toxic effects exerted by $A$. indica extract on the liver.

\section{Data Availability}

The data used to support the findings of this study are included within the article.

\section{Disclosure}

This study was performed as part of the employment of the authors at the Universities of Ngaoundere and Yaounde I, providing all the necessary facilities.

\section{Conflicts of Interest}

The authors declare that there are no conflicts of interest regarding the publication of this paper.

\section{Acknowledgments}

The authors are thankful to Mister Nana, a traditional healer facilitating our contact with others and collecting the plant, and to Professor Mapongmetsem Pierre Marie, a plant taxonomist at the University of Ngaoundere (Cameroon), for the identification of plants.

\section{Supplementary Materials}

Table S1: plants used in the treatment of malaria in Dibbi locality. Table S2: behavioural observations of acute toxicity study with Erigeron floribundus and Azadirachta indica. (Supplementary Materials)

\section{References}

[1] WHO, “World malaria report," 280p, 2015, http://www.who.int/ malaria.

[2] L. Cui, S. Mharakurwa, D. Ndiaye, P. K. Rathod, and P. J. Rosenthal, "Antimalarial drug resistance: Literature review and activities and findings of the ICEMR network," The American Journal of Tropical Medicine and Hygiene, vol. 93, pp. 57-68, 2015.

[3] P. K. T. Munishi, R. A. P. C. Temu, and G. Soka, "Plant communities and tree species associations in Miombo ecosystems in Lake Rukwa basin, Southern Tanzania: Implications for conservation," Journal of Ecology and The Natural Environment, vol. 3, no. 2, pp. 63-71, 2011.

[4] O. S. Olorunnisola, A. Adetutu, E. A. Balogun, and A. J. Afolayan, "Ethnobotanical survey of medicinal plants used in the treatment of malarial in Ogbomoso, Southwest Nigeria," Journal of Ethnopharmacology, vol. 150, no. 1, pp. 71-78, 2013.

[5] N. Tsabang, P. V. T. Fokou, L. R. Y. Tchokouaha et al., "Ethnopharmacological survey of Annonaceae medicinal plants used to treat malaria in four areas of Cameroon," Journal of Ethnopharmacology, vol. 139, no. 1, pp. 171-180, 2012.

[6] V. B. Yaw, A. S. Osafo, and A. G. Ben, "Ethnobotanical survey of plants used in the treatment of malaria in the sekyere central district of ashanti region of Ghana," International Journal of Novel Research in Life Sciences, vol. 2, no. 6, pp. 17-25, 2008. 
[7] V. PK Titanji, D. Zofou, and M. Ngemenya, "Malaria Treatment in African Folk Medicine: An Investigation on Medicinal Plant Products Used in Cameroon," International Journal of Infectious Diseases, vol. 12, p. e306, 2008.

[8] M. L. Willcox and G. Bodeker, "Traditional herbal medicines for malaria," British Medical Journal, vol. 329, no. 7475, pp. 11561159, 2004.

[9] M. Farahna, S. Bedri, S. Khalid, M. Idris, C. Pillai, and E. Khalil, "Anti-plasmodial effects of Azadirachta indica in experimental cerebral malaria: Apoptosis of cerebellar Purkinje cells of mice as a marker," North American Journal of Medical Sciences, pp. 518-525, 2010.

[10] L. A. Oseni and G. M. Akwetey, "An in-vivo evaluation of antiplasmodial activity of aqueous and ethanolic leaf extracts of Azadirachta indica in Plasmodium berghei infected balb/c mice," International Journal of Pharmaceutical Sciences and Research, vol. 3, no. 5, pp. 1406-1410, 2012.

[11] N. K. Achi, C. Onyeabo, and D. A. Nnate, "Therapeutic effects of Azadirachta indica A. Juss. Leaves in malaria-induced male winstar rats," Journal of Pharmacy Pharmacognosy Research, vol. 6, no. 3, pp. 191-204, 2018.

[12] F. Tra Bi, M. Koné, and N. Kouamé, "Antifungal activity of Erigeron floribundus (Asteraceae) from Côte d'Ivoire, West Africa," Tropical Journal of Pharmaceutical Research, vol. 7, no. 2, 2008 .

[13] E. A. Asongalem, H. S. Foyet, J. Ngogang, G. N. Folefoc, T. Dimo, and P. Kamtchouing, "Analgesic and anti-inflammatory activities of Erigeron floribundus," Journal of Ethnopharmacology, vol. 91, no. 2-3, pp. 301-308, 2004.

[14] P. B. Telefo, L. L. Lienou, M. D. Yemele et al., "Ethnopharmacological survey of plants used for the treatment of female infertility in Baham, Cameroon," Journal of Ethnopharmacology, vol. 136, no. 1, pp. 178-187, 2011.

[15] B. A. E. Loufoua, D. J. Bassoueka, G. F. Nsonde Ntandou et al., "Phytochemical, pharmacological and ethnobotany study of some Congolese plants with potential antitussive," Phytotherapy Research, vol. 13, no. 6, pp. 377-383, 2015.

[16] A. E. Tahir, G. M. H. Satti, and S. A. Khalid, "Antiplasmodial activity of selected Sudanese medicinal plants with emphasis on Maytenus senegalensis (Lam.) Exell.," Journal of Ethnopharmacology, vol. 64, no. 3, pp. 227-233, 1999.

[17] M. A. Alshawsh, R. A. Mothana, H. A. Al-shamahy, S. F. Alsllami, and U. Lindequist, "Assessment of Antimalarial Activity against Plasmodium falciparum and Phytochemical Screening of Some Yemeni Medicinal Plants," Evidence-Based Complementary and Alternative Medicine, vol. 6, Article ID 653926, 4 pages, 2009.

[18] G. N. Zirihi, L. Mambu, F. Guédé-Guina, B. Bodo, and P. Grellier, "In vitro antiplasmodial activity and cytotoxicity of 33 West African plants used for treatment of malaria," Journal of Ethnopharmacology, vol. 98, no. 3, pp. 281-285, 2005.

[19] K. Tano, W. Yavo, J. Trebissou et al., "Ex vivo Antiplasmodial Activity of Plant Extracts Used in Traditional Medicine in Côte d'ivoire," Journal of Advances in Medical and Pharmaceutical Sciences, vol. 3, no. 4, pp. 172-179, 2015.

[20] R. S. Yerbanga, L. Lucantoni, G. Lupidi et al., "Antimalarial plant remedies from Burkina Faso: Their potential for prophylactic use," Journal of Ethnopharmacology, vol. 140, no. 2, pp. 255-260, 2012.

[21] O.-A. Kingsley, A. Oseni, and O. Quasie, "A comparative evaluation of in vivo antiplasmodial activity of aqueous leaf extracts of Carica papaya, Azadirachta indica, Magnifera indica and the combination there of using Plasmodium infected Balb/c," International Journal of phytopathology, vol. 3, no. 3, pp. 372378, 2012.

[22] W. Peters, "Drug resistance in Plasmodium berghei Vincke and Lips, 1948. I. Chloroquine resistance," Experimental Parasitology emphasizes, vol. 17, no. 1, pp. 80-89, 1965.

[23] J. R. Zucker and C. C. Campbell, "Malaria: Principles of prevention and treatment," Infectious Disease Clinics of North America, vol. 7, no. 3, pp. 547-567, 1993.

[24] OECD 425, "OECD guidelines for the testing of chemicals. Acute Oral Toxicity - Up-and-Down-Procedure (UDP)," 27p, 2008.

[25] OECD 407, "OECD guidelines for the testing of chemicals. Repeated Dose 28 -Day Oral Toxicity Study in Rodents," 14p, 2008.

[26] M. L. Willcox, G. Bodeker, and P. Rasoanaivo, Traditional medicinal plants and malaria, Boca Raton CRC, 2004.

[27] S. MacKinnon, T. Durst, J. T. Arnason et al., "Antimalarial Activity of Tropical Meliaceae Extracts and Gedunin Derivatives," Journal of Natural Products, vol. 60, no. 4, pp. 336-341, 1997.

[28] D. H. Bray, D. C. Warhurst, J. D. Connolly, M. J. O’Neill, and J. D. Phillipson, "Plants as sources of antimalarial drugs. Part 7. Activity of some species of meliaceae plants and their constituent limonoids," Phytotherapy Research, vol. 4, no. 1, pp. 29-35, 1990.

[29] K. Murugan and C. P. lvam, "Antimalarial potential of neem limonoids against Plasmodium falciparum," International Journal of Current Medical Sciences, vol. 3, no. 1, pp. 5-9, 2003.

[30] J.-R. Kuiate, A. A. Tsona, J. Foko, J. M. Bessiere, C. Menut, and P.-H. A. Zollo, "Chemical composition and in vitro antifungal properties of essential oils from leaves and flowers of erigeron floribundus (H.B. Et K.) Sch. Bip. From cameroon," Journal of Essential Oil Research, vol. 17, no. 3, pp. 261-264, 2005.

[31] S. Afoulous, H. Ferhout, E. G. Raoelison et al., "Helichrysum gymnocephalum essential oil: chemical composition and cytotoxic, antimalarial and antioxidant activities, attribution of the activity origin by correlations," Molecules, vol. 16, pp. 8273-8291, 2011.

[32] J. O. Suberu, A. P. Gorka, L. Jacobs et al., "Anti-plasmodial polyvalent interactions in Artemisia annua L. aqueous extract - Possible synergistic and resistance mechanisms," PLoS ONE, vol. 8, no. 11, 2013.

[33] C. Berto, F. Maggi, P. C. B. Nya, A. Pettena, I. Boschiero, and S. Dall'Acqua, "Phenolic constituents of erigeron floribundus (asteraceae), a cameroonian medicinal plant," Natural Product Communications (NPC), vol. 9, no. 12, pp. 1691-1694, 2014.

[34] A. M. Lehane and K. J. Saliba, "Common dietary flavonoids inhibit the growth of the intraerythrocytic malaria parasite," BMC Research Notes, vol. 1, no. 1, p. 26, 2008.

[35] J. Langhorne, S. J. Quin, and L. A. Sanni, "Mouse Models of Blood-Stage Malaria Infections: Immune Responses and Cytokines Involved in Protection and Pathology," in Malaria Immunology, P. Perlmann and M. Troye-Blomberg, Eds., Stockholm, Karger publisher, pp. 204-228, 2002.

[36] B. Mengiste, E. Mekonnen, and K. Urga, "In vivo animalarial activity of Dodonaea angustifolia seed extracts against Plasmodium berghei in mice model," MEJS, vol. 4, pp. 147-163, 2012.

[37] L. Bantie, S. Assefa, T. Teklehaimanot, and E. Engidawork, "In vivo antimalarial activity of the crude leaf extract and solvent fractions of Croton macrostachyus Hocsht. (Euphorbiaceae) 
against Plasmodium berghei in mice," BMC Complementary and Alternative Medicine, vol. 14, article 79, 2014.

[38] P. A. Tarkang, F. A. Okalebo, L. S. Ayong, G. A. Agbor, and A. N. Guantai, "Anti-malarial activity of a polyherbal product (Nefang) during early and established Plasmodium infection in rodent models," Malaria Journal, vol. 13, no. 1, article no. 456, 2014.

[39] A. Nardos and E. Makonnen, "In vivo antiplasmodial activity and toxicological assessment of hydroethanolic crude extract of Ajuga remota," Malaria Journal, vol. 16, no. 1, article no. 25, 2017.

[40] K. Kanagasanthosh, S. Shanmugapriyan, and V. Kavirajan, "Evaluation of acute toxicity, anti-inflammatory activity and phytochemical screening of ethanolic extract of Azadirachta indica leaves," International Journal of Research and Development in Pharmacy \& Life Sciences, vol. 4, pp. 1737-1742, 2015.

[41] P. Kamdem Boniface, M. Singh, A. Kumar Maurya, and A. Pal, "Acute and sub-chronic toxicity of HPLC fingerprinted extract of Conyza sumatrensis (Retz.) E.H. Walker in rodents," Journal of Ethnopharmacology, vol. 149, no. 3, pp. 833-837, 2013.

[42] P. Kumar, M. Suba, and V. B. Ramireddy, "Acute and SubAcute (28 Day) Oral Toxicity Studies of Ethanolic Extract of Celtis Timorensis Leaves in Rodents," Global Journal of Medical Research: B Pharma, Drug Discovery, Toxicology and Medicine, vol. 14, no. 3, pp. 6-14, 2014. 


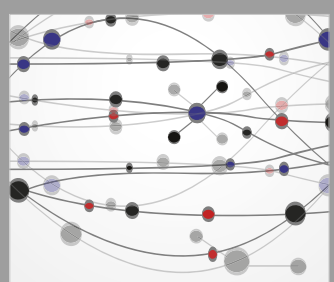

The Scientific World Journal
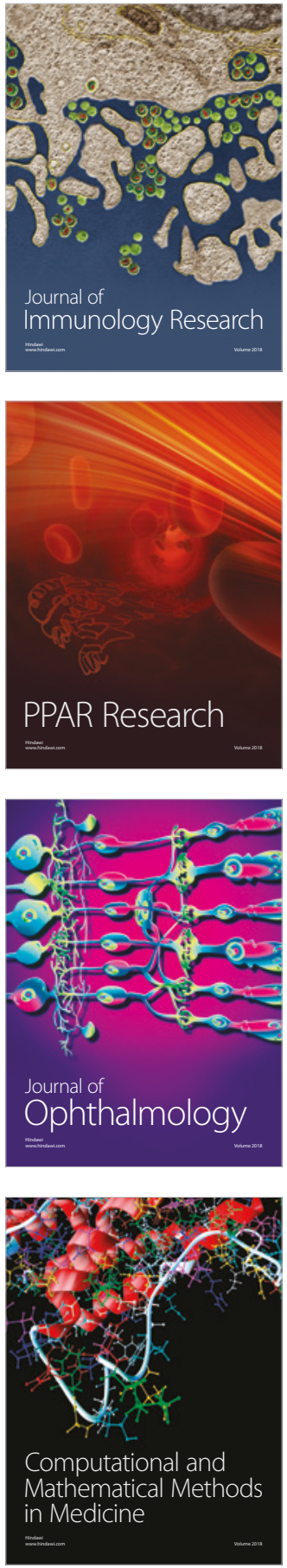

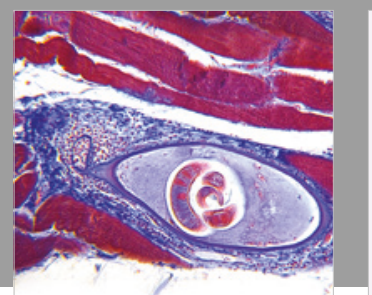

Gastroenterology Research and Practice

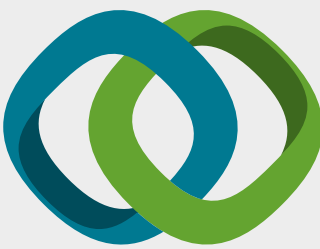

\section{Hindawi}

Submit your manuscripts at

www.hindawi.com
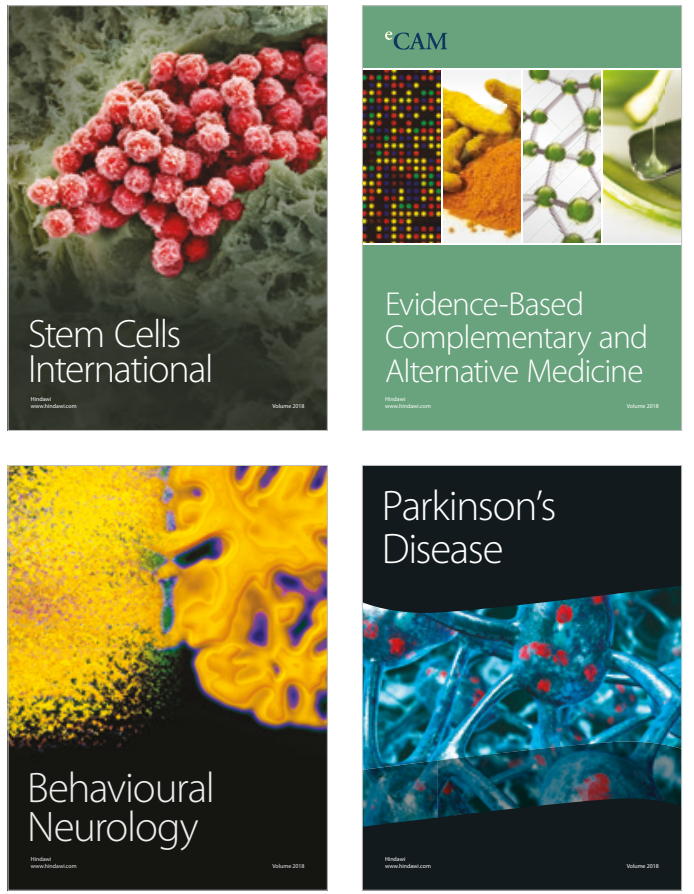

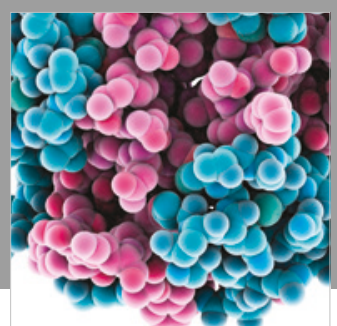

ournal of

Diabetes Research

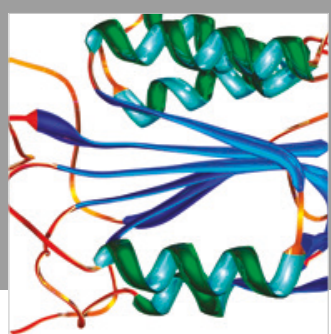

Disease Markers
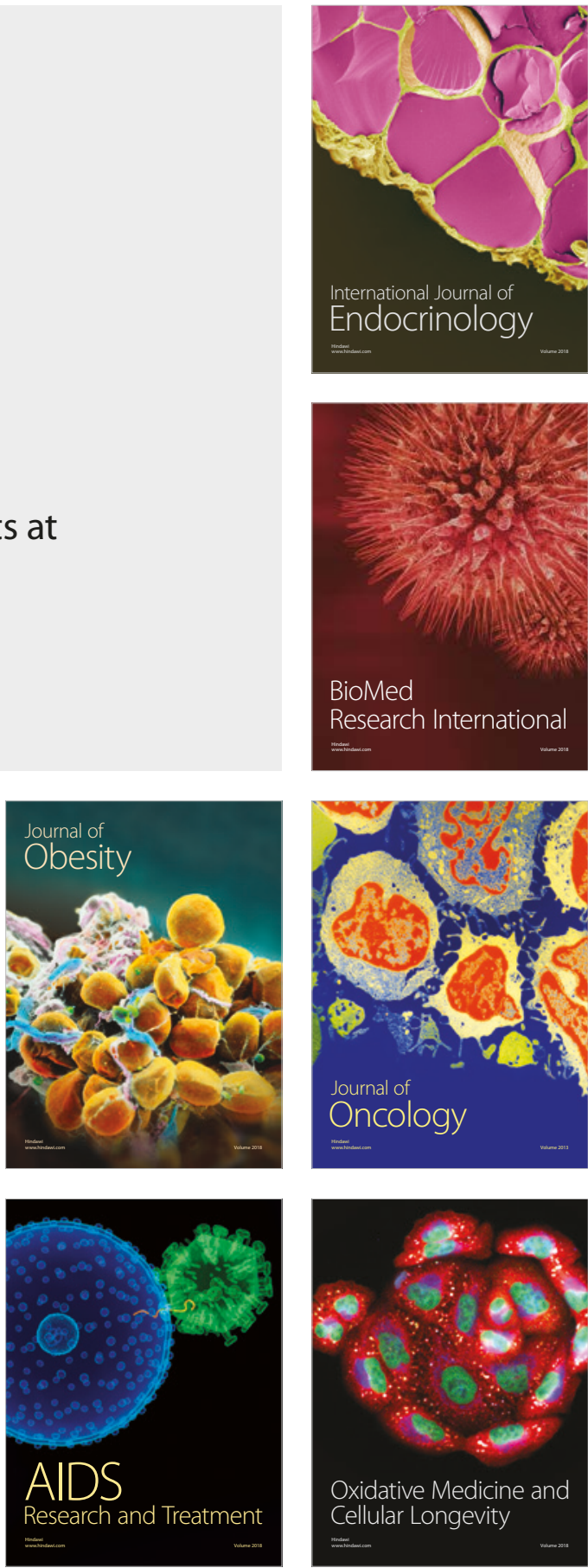